\title{
Az IT-megoldások szerepe Szöul fenntartható várossá alakításában
}

A legtöbb nagyváros küzd a túlzsúfoltságból adódó környezeti, gazdasági és társadalmi gondokkal, különösen igaz ez a világ legsűrűbben lakott városára, Szöulra. A városok fenntarthatósága globális erőforrás-gazdálkodási kérdés, megoldása a városok irányításának a szintjén is globális felelősség, koncepciója a fenntartható fejlődésből az ökológiai gondolkodások keresztül fejlődött, és máig mindenütt meghatározza a városirányítást. A városok ökológiai és energiagazdálkodási gondjai azonban csak részlegesen oldhatók meg szabályozókkal és infrastrukturális beruházásokkal, legalább ennyire fontos az emberek értékrendjének megváltoztatása, a környezettudatos magatartás kifejlődésének elősegítése. E cél megvalósítása érdekében Szöul vezetése hatékony információtechnológiai eszközök bevezetésére vállalkozott. Ebben a tanulmányban a fenntarthatóság központi koncepcióján keresztül közelítjük meg a fenti problematikát, és alternatív válaszokat mutatunk be, melyek alkalmasak a környezeti problémák társadalmi szintű megoldására, különös tekintettel a IT-eszköztárra.

Kulcsszavak: fenntartható város, Szöul, intelligens városfejlesztés, zöld város

\section{Szerzői információ}

Koudela Pál, Kodolányi János Egyetem

ORCID ID: 0000-0002-2809-610X

Így hivatkozzon erre a cikkre:

Koudela Pál. „Az IT-megoldások szerepe Szöul fenntartható várossá alakításában”. Információs Társadalom XXI, 1. szám (2021): 143-165.

$=$ https://dx.doi.org/10.22503/inftars.XXI.2021.1.6 $\rightleftharpoons$

A folyóiratban közölt müvek

a Creative Commons Nevezd meg! - Ne add el! - Így add tovább! 4.0

Nemzetközi Licenc feltételeinek megfelelóen használhatók. 


\section{The role of IT solutions in making Seoul a sustainable city}

Most major cities are struggling with the environmental, economic and social problems of overcrowding, especially in the world's most densely populated city, Seoul. Urban sustainability is a global resource management issue, solving it at the level of urban governance is also a global responsibility, its concept of sustainable development has evolved through ecological thinking and still defines urban governance everywhere today. However, the ecological and energy management problems of cities can only be partially solved by regulators and infrastructure investments, it is at least as important to change the values of people and to promote the development of environmentally conscious behavior. To this end, the leadership of Seoul undertook the introduction of effective information technology tools. In this study, we approach the above issues through a central concept of sustainability and present alternative responses that are suitable for solving environmental problems at the societal level, with particular reference to the IT toolkit.

Keywords: sustainable city, Seoul, smart urban development, green city 


\section{A fenntarthatóság eszközei}

A fenntartható város fogalma leginkább a fenntartható fejlődéshez köthető, kiindulópontja és fundamentuma Gro Harlem Brundtland 1987-es ENSZ-nek tett jelentése. A rákövetkező bő három évtizedben az „olyan fejlődés, amely kielégíti a jelen szükségleteit anélkül, hogy veszélyeztetné a jövő nemzedékek esélyét arra, hogy ők is kielégíthessék szükségleteiket” mottója határozta meg a fenntartható városok koncepcióját is. Ennek az elvnek számtalan dimenziója létezik, ám mindegyiket megelőzi az ökológiai fenntarthatóság szerepe. Ennek talán legismertebb modellje az ökológiai lábnyom, William Rees és Mathis Wackernagel (1996) közös alkotása. Szinte minden, a témával foglalkozó munka azzal kezdődik, hogy az urbanizáció - energia és árufogyasztás tekintetében - a végletekig növelte a városok központi szerepét, a növekvő globális ökológiai hanyatlás következtében azok már nem önfenntartók. A városok szerepe ezáltal kiemelkedik a globális fenntarthatóság kérdéskörében. Továbbá mivel tehát a város önmagában nem fenntartható, annak fenntarthatósága megegyezik a globális hinterlandéval. A város strukturált disszipatív nyitott rendszer ${ }^{1}$ - saját rendjét és annak fejlődését csak a környezete fokozott degradálásával tudja fenntartani - ezt nevezte Rees és Wackernagel „entrópiás fekete lyuknak”.

Megállapítjuk, hogy a Földön rendelkezésre álló terület fejenként 1,5 hektár, a globális ökológiai lábnyom ezt meghaladva már 2013-ban 2,8 hektár volt, így ha mindenki észak-amerikai színvonalon élne, akkor fejenként 6 hektár földre volna szükség. A városok felelőssége, hogy csökkentsék a környezet terhelését a koncentrált szennyezés elosztása és ciklikus lokális anyagáramlási rendszerek fenntartása (például foszfor) révén. A városoknak ugyanakkor vannak előnyei is: alacsonyabb az egy főre jutó ivóvízellátási, csatornázási, hulladékgyüjtési stb. költségük; jobb és több lehetőségük adódik az újrahasznosítás terén (valamint allokáció és ipar terén is); nagyobb a népsürüségük, tehát kevesebb az elfoglalt terület; méretgazdaság és kapcsolt energiatermelés jellemzi őket; az energiafogyasztás csökkentése az emberek egymáshoz való közelsége révén (például gyalogos vagy tömegközlekedés) könnyebben megoldható, mint más települési formáknál; függő viszonyaik csökkentése érdekében fejleszthetik közvetlen forrásaikat (Rees és Wackernagel 1996).

A fentiek nem egyszerü bevezetésként szolgálnak, jól mutatják azt az irányt is, amit nagy hatású megfogalmazói kijelöltek a városvezetés, -kutatás, -tervezés, -gazdálkodás és -elemzés terén. A környezeti és ökológiai szempontok a városok fejlesztésében és irányításában, azok költségvetésének alakításában, továbbá a környezetszennyezés kezelésében, az energiagazdálkodás és infra-

\footnotetext{
${ }^{1}$ A disszipatív rendszerekre az jellemző, hogy a mozgás, időbeli változás során a rendszer teljes energiáját folyamatosan csökkenti valamilyen veszteségekkel járó folyamat, például súrlódás, közegellenállás, hőleadás következtében.
} 
struktúra átalakításában, illetve fenntarthatóvá alakításában meghatározó jelentőségűek. Az építészet terén jól példázzák ezt az öko-ipari parkok, a városi gazdálkodás és kertészkedés, a közlekedés terén az autómentes vagy automatizált okosváros-fejlesztések, vagy magának a környezeti diverzitásnak az elősegítése és fizikai összetevőinek fejlesztése.

Mindezek az elemek tehát a már meglévő városszerkezet átalakításának, egy új városrész tervezésekor pedig az újonnan épülő alapvető elemeknek a részét képezik - Koreában remek példa erre Szongdo okosváros (Townsend 2013, Rugkhapan 2019, Mullins 2017). Az alacsonyabb károsanyag-kibocsátás vagy a zöldtetők lényegében egy általánosabb szempontrendszerbe kapcsolódnak Szöul esetében is, melyről ékesen szól a várost körülölelő zöldöv, a városi zöldutak és a hozzájuk kapcsolódó számtalan ökológiai, gazdasági és társadalmi probléma. Vannak azonban más eszközök is, amivel egy olyan nagyváros, mint Szöul fenntarthatóbbá tehető. Az átalakulást segítő eszközök közül csak az egyik a technológia (melynek fejlesztésén oly nagy hangsúly van Koreában), legalább ennyire fontos az emberi tényező is. A következőkben arra igyekszünk példákat mutatni, hogyan lehet nem csupán a közvetlen szabályozókkal és technológiai innovációkkal, azok bevezetésével, vagy a fizikai környezet nagyszabású átalakításával, hanem infokommunikációs eszköztárral és azon keresztül az értékrendszer és a szokások befolyásolásával is csökkenteni egy nagyváros környezeti terhelését. Az alulról szervezett városfejlesztés, egy alapvetően állami irányítású nemzet- és városgazdaságban, ahol az állami irányítás mellett a csebolok ${ }^{2}$ uralják a piacot, különösen fontos, értékhordozó kérdés. A fejlesztő állami (Johnson 1982) szerepkör, a globalizációhoz való alkalmazkodás meghatározó Japánban és Dél-Koreában egyaránt, így a kulturális környezetre és az egyénre támaszkodó eszközök együttese olyan tényező, ami nagyobb figyelmet igényel, mint amit ez idáig az elemzések révén kapott.

A városok ökológiai problémái, s Szöul sajátos helyzete is alaposan feltárt terület, az ökológiai problémák kezelésére felhasznált eszközök széles spektrumát is sokszor kutatták, feldolgozták már (Ahn 2015, Cho 2013, Jeon 2011, Shin és Jeong 2010), Szöul egyes területeinek fejlesztései és azok ökológiai és gazdasági hatásmechanizmusa, esetenként azok társadalmi következményei is széleskörben megvitatott és elemzett témák. Mindezek egységes rendszerezése azonban nem történt meg, a városirányítás és a város társadalmának kapcsolata a nemrég elhunyt Pak Vonszun vezetésével hozott jelentős fordulatot, így azok az eszközök, melyek a város lakosságát közvetlenül szólítják meg, és személyes jelenlétet igényelnek, 2011 után nagyobb szerepet kezdtek játszani. Mindezek fényében az állami-fővárosi ${ }^{3}$ nagy beruházásokon túl

\footnotetext{
${ }^{2}$ Családi alapítású megavállalatok, mint a Samsung vagy a Hyundai.

${ }^{3}$ Szöul polgármestere a második legfontosabb állami pozíció. Koreában legtöbb esetben a magántőkével történő beruházások is állami irányítással, s minden esetben állami ellenőrzés alatt valósulnak meg.
} 
fontosnak ítéltük azon eszközök bemutatását, melyek elősegítik a társadalom alulról történő szerveződését. Ugyanakkor a technológia gyors fejlődése is alátámasztja, hogy az IT-eszközök alkalmazását elkülönítve tárgyaljuk az olyan nagyszabású beruházásoktól, mint a zöldöv vagy a területi-infrastrukturális fejlesztések. A továbbiakban igyekszünk hangsúlyt fektetni a lakossági részvétel szerepére, s a környezeti fejlesztésben egyre nagyobb hangsúlyt kapó sajátos kulturális tényezőkre, mint a területi identitás és spiritualitás.

Talán furcsa a spiritualitás szerepét keresni egy modern nagyváros fejlesztésének IT-technológiáit bemutató tanulmányban, ám ha arra gondolunk, hogy a közösségfejlesztés egyik legfontosabb eleme a templom, hogy az alig néhány évtizedes múltra visszatekintő mecset Ithevonban máris egészen új szerveződési formákat hozott létre Szöulban, s hogy egy-egy fontosabb döntés előtt még a Samsung vezetője is mudang ${ }^{4}$ tanácsát kéri, akkor megítélésünk egészen megváltozik. Nem hiába írja Don Baker (2008: 1) a következőket: „...a Szöuli Szongpa kerületében található apartmantól egy rövid séta alatt egyszerre értem a többszáz zsúfolt üzletekkel teli hatalmas bevásárlóközponthoz, és egy nyüzsgő buddhista templomhoz, mely szintén hatalmas tömegeket vonz magába. A sarkon orvosi rendelőintézetek sorakoztak, mögöttük egy sámán irodája következett az utcában. A lakáshoz legközelebb eső kereszteződésben egy keresztény könyvesbolt állt, amely a mennybe jutásról szóló könyveket árult, osztozva egy taoista központtal, ahol fizikai gyakorlatokat és légzési technikákat tanítottak, s egészséget és hosszú életet ígértek.” A városfejlesztés eszközeinek bemutatása, a sajátos kontextus kihangsúlyozása mindenképpen új mondanivaló.

\section{Szöul környezeti problémái}

Az 1908 és 2007 között eltelt időszak alatt a föld átlagos hőmérséklete 0,74 C fokot emelkedett. Ez az érték Koreában 1,5 C volt, Szöul átlaghőmérséklete azonban 2,4 $\mathrm{C}^{\circ}$-kal nőtt ugyanebben az időszakban. 2009-ben Korea 564 millió tonna CO2-nek megfelelő üvegházhatású gázt bocsátott ki, ennek 8,7\%-a (49 millió tonna) Szöulból származik. Más városoktól eltérően, Szöulban az üvegházhatást okozó gázok kibocsátásának 94\%-át lakó- és kereskedelmi épületek, valamint autók generálják, ezért Szöulban a kibocsátás csökkentésének legjobb módja, ha az energiatakarékossági programokat az otthonokra és munkahelyekre összpontosítják. Más megközelítésben, az üvegházhatást okozó gázok kibocsátásának jellemzőire vonatkozó felmérés szerint Szöulban a háztartások és az épületek a kibocsátás 67\%-át, a közlekedés pedig annak 24\%-át teszi ki. Ez a két terület az üvegházhatású gázok teljes kibocsátásának több mint 90\%-át

\footnotetext{
${ }^{4}$ Mudang a koreai sámán, a modern társadalomban betöltött szerepéről lásd: (Koudela és Yoo 2014).
} 
teszi ki, így a fővárosban a rövid távú gázkibocsátás csökkentésének leghatékonyabb módja a háztartások és a vállalkozások önkéntes részvétele az energiamegtakarításban (Eco-Mileage System). Egy norvég felmérés szerint Szöulban és annak nagyvárosi térségében az éves CO2 kibocsátás 276 millió tonna, a koreai főváros tehát a legnagyobb károsanyag-kibocsátó, s a legnagyobb ökológiai lábnyomot tudhatja magáénak a világon (Moran et al. 2018).

Ahogy az ipar fejlődése a 70-es években lendületet vett, úgy nőtt a károsanyag-kibocsátás is Korea-szerte, az ipar és a népesség koncentrációjának megfelelően, különösen Szöulban és annak agglomerációjában. Korea fejlett gazdasággá válásával és Szöul globális pozíciójának emelkedésével számos környezetvédelemre vonatkozó törvény látott napvilágot, melyek közé tartozik a zöldöv védelme és az üvegházhatású gázok kibocsátásának korlátozása. Mindez alapvetően javított Szöul levegőjének minőségén, ám az továbbra is meglehetősen szennyezett, s a többi OECD-ország nagyvárosaival összehasonlítva, itt a legrosszabb a levegőminőség a szálló por és az ózon tekintetében is.

A 2005 és 2013 közötti időszakban a légszennyezéshez köthető korai halálesetek ${ }^{5}$ 29\%-kal nőttek Koreában, ám 2060-ra várhatóan még ez is megháromszorozódik majd, annak ellenére, hogy a 2005-ben és 2008-ban bevezetett szabályozások hatására 2001 és 2014 között a PM10 szállópor és a NO2 mennyisége a felére csökkent. Szöul nagyvárosi térsége így is a harmadik helyen áll a szállópor mennységét tekintve a 291 OECD nagyvárosi térség között (OECD 2017a). A levegőszennyezettség felét a helyi ipar és energiatermelés adja, a másik felét az oly sokszor kárhoztatott széljárás, ami főként Kínából hozza át a port (Hu 2017). Jelentős azonban a közlekedés hozzájárulása is. Szöul egyes kerületeit összehasonlítva fontos kiemelni, hogy a levegő szennyezettsége jobban sújtja a belvárosi és északi, alapvetően alacsonyabb jövedelmű és idősebb népességű kerületeket.

A 90-es évektől ugyancsak súlyos problémákat jelent a víz hiánya és rossz minősége; ennek közvetlen szabályozása, így a vízhasználati díjak differenciálása sem oldotta meg a problémát. Nemcsak a folyók és a tengervíz ipari szennyezése okoz gondot Szöul nagyvárosi területén, de a legtöbben a csapvizet is csak felforralás után tudják felhasználni (Choi et al. 2017). 2005-ben egy tízéves terv látott napvilágot Szöul levegőminőségének javítására, 2015-ben újabb tervezési időszak indult útjára, ám ebben az időszakban már a természeti környezet helyreállítása is nagyobb hangsúlyt kapott. Az Environmental Performance Index (EPI) adatközpontú összefoglalót nyújt a fenntarthatóság helyzetéről a világ minden tájáról. Az EPI 180 országot rangsorol a környezeti egészség és az ökoszisztéma vitalitása szempontjából 11 teljesítménykategória és 32 teljesítménymutató felhasználásával. Az EPI Dél-Koreát 2016-ban még összességében a 80-adik, ám a levegőminőség tekintetében a 173-adik helyre rangsorolta (EPI 2016) 2020-ban az összesített indexérték alapján és a levegőminőség tekintetében is már a 28-adik helyen állt az ország (EPI 2020).

${ }^{5}$ A korai halálozás az adott populációban az átlagos halálozási kor alatti halálozásokat jelöli. 


\section{Jelmagyarázat}

(\%) Háztartások 1800 dollár jövedelem alatt
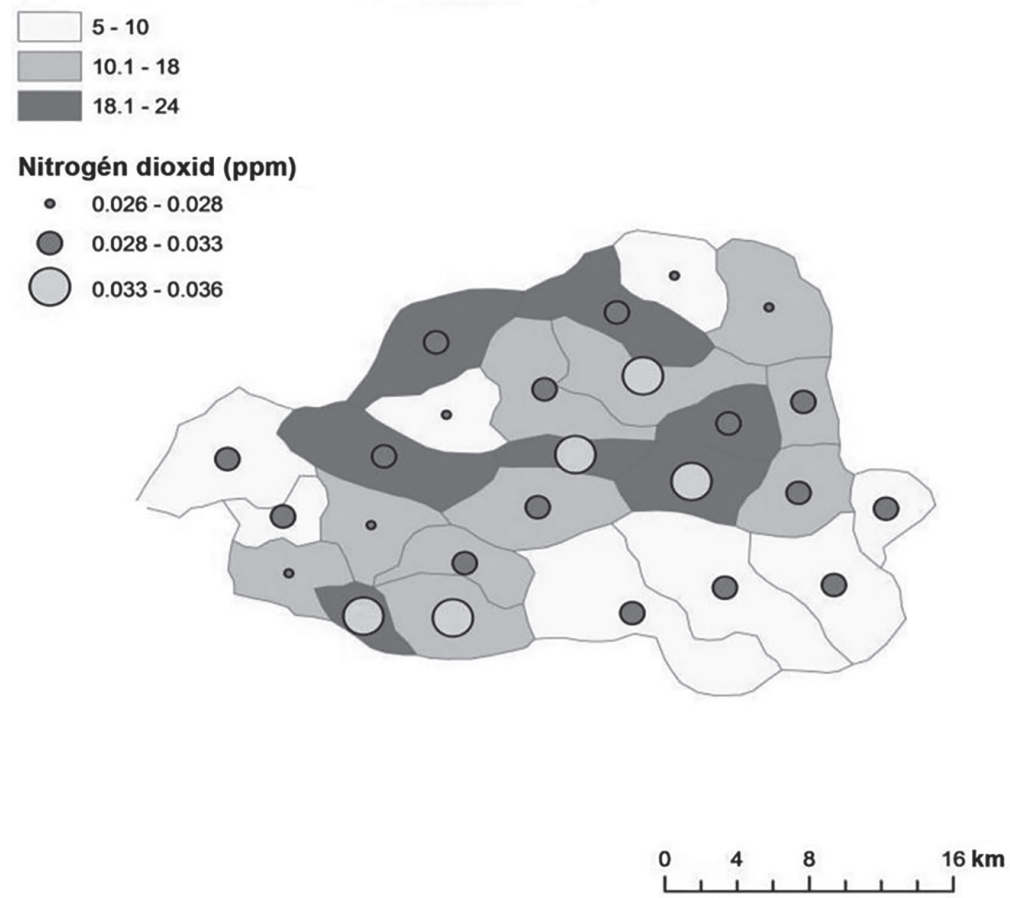

1. ábra: Szöul légszennyezettsége és átlagos jövedelmei kerületi bontásban (saját szerkesztés OECD 2018 alapján)

\section{A környezeti problémák kezelésének módszerei és annak korlátjai}

Szöul fenntarthatóvá tételéhez a város vezetése számos eszközt igénybe vett az elmúlt évtizedek során. Ide sorolhatóak a várost körülölelő zöldöv, a város legkülönbözőbb részeit érintő revitalizációs és rehabilitációs projektek, a dzsentrifikációt szolgáló parkosítások és az infrastruktúrafejlesztés egyes elemei egyaránt. Ebben a tanulmányban kifejezetten az ökológiai környezet javítása érdekében használt legújabb IT-eszközökkel foglalkozunk, de nem mehetünk el szó nélkül azon fejlesztések mellett sem, melyekbe mindez beágyazódik.

Szöul fent vázolt fizikai környezetét meghatározó ökológiai problémái már a japán megszállás idején jelentősek voltak, ám a város a koreai háború utáni években olyan mértékű népességkoncentrációt élt meg, melyre korábban nem volt példa. Az északról menekülők nagyobb része a belvárosban, nyomortelepeken élt, a város történelmi központját kelet-nyugati irányban kettészelő Cshonggjecshon patak mentén, melynek szennyezettsége az 50-es évekre elviselhetetlenné vált. A probléma megoldására nem láttak jobb megoldást, mint a patak befedése, mely 1958-ban kezdődött. A patakból csatorna lett, s az azt borító új betonburkolatra közút került, partjain a nyomornegyedeket gyárak és piacok kezdték felváltani. 1977-re majdnem a teljes hosszában a járdaszint alatti részt leburkolták és a városközpont ütőereként egy emelt szintű autópá- 
lyát építettek fölé. A kerület átalakult, ám korántsem szabadult meg a környezeti problémáktól. Az út forgalma évről évre nőtt, 2002-ben már napi 170 ezer jármű haladt át rajta (Kurniawan 2016).

A hetvenes évek után ezt a környéket a zsúfolt kisüzemek és a munkaerő kizsákmányolása tette hírhedté. Az 1997-es gazdasági válságot követő években a sztráda árnyékában meghúzódó piszkos utcák a gazdasági fejlődés negatív irányát juttatták eszébe mindenkinek, nem csoda, hogy éppen ekkor merült fel a gondolat a patak újbóli feltárására, és az egész terület rekonstrukciójára. Cshonggjecshon felújítása illeszkedett a 2000-es évek várostervezési szemléletébe. Ekkor vált uralkodóvá az ökológiai és történelmi szempont, a parkok már nem csak rekreációs szerepet töltöttek be, hanem a város természetes környezetét bővítették, javították, a történelmi emlékek kiemelt jelentőséget kezdtek kapni. A várostervezők igyekezték a főváros hatszázéves történelmét a város mindennapjaiban, az utcákon is tetten érhető identitássá változtatni. A Kvakhvamun Kapu felújítása 2006 és 2009 között, valamint az azonos nevű park felépítése hasonlóképp jól példázza a városrehabilitáció 21. század eleji trendjét, de említhetnénk a kétezres évek elején az erdőlétesítési tervet is, ami nem hagyományos parkokat, hanem természetes erdők telepítését tűzte ki célul (Csong 2014).

A 2003-4-ben zajló felújítás, habár sok romantikus elképzelés is kapcsolódott hozzá, nem volt olyan egyszerü. Egyrészt valódi indokai az erodáló sztráda és romló környezete, annak veszélyei, a környék revitalizációja és a környezetszennyezés megszüntetése voltak, másrészt a patak vízhozamát eredetileg kiadó mellékágakat idővel mind becsatornázták, így lényegében ma is a Han folyóból kell napi 98 ezer tonna vizet átszivattyúzni a patakba, ami aztán visszafolyik a Han folyóba. Mindezt a közeli metróállomáson összegyülő vízzel egészítik ki. Ekkora mennyiségű vizet minden nap felszivattyúzni természetesen hatalmas energiafelhasználást, következésképpen környezeti terhelést jelent, ami ellentmond az egész terv ökológiai céljának (Cho, M-R 2010). A fentiek fényében a patak inkább az infrastruktúrafejlesztés technológiai eredménye, mintsem a természeti környezet visszaállítása lett: más szavakkal élve, sokkal inkább szökőkúttá lett, mintsem visszanyerte patak jellegét (Rieh és Chang 2018: 132).

A közéleti szakemberek általános véleménye negatív volt, a közvélemény körében és a turisták számára azonban igen népszerű lett a fejlesztés. Matthias Gross (2002; 2003; 2005) az ökológiai helyreállítást egyfajta „társadalmi kísérletnek" nevezi: a társadalom és a természet kapcsolatának. Mindez azonban attól függ, hogyan értelmezik az emberek a természetet, és hogyan használják fel a természet értékeit és elemeit a meglévő kulturális kontextusban és intézményekben. A kritikák egy része az ökológiai problémákra fókuszált, hiszen a patak vizét mesterségesen kell pótolni a Han folyóból, másik része azonban a hibás és hiányos történeti rekonstrukcióra hívta fel a figyelmet. A felújítás célja azonban nem állt meg a természeti-történeti rekonstrukciónál, az egész belvárosi környezet dzsentrifikációját szándékozott előmozdítani, s a város déli, az ezredfordulóra messze fejlettebb városrészeihez (például Kangnam) történő felzárkózást is igyekezett elősegíteni. 
Mindezt összevetve a legfontosabb kérdés az lehet, hogy az újonnan kialakított terület milyen identifikációt hozott létre: patak vagy történelmi emlékmű, esetleg magas presztízsű belvárosi, üzleti vagy lakóövezet. Ha a városkép fejlesztésére, a turisztikai iparág növekedésére és az ebből származó bevételekre helyezzük a hangsúlyt, kiegészítve további fejlesztésekkel a város peremterületén, akkor egyértelműen pozitív az összkép. Ha a lokális közösségek autonómiáját, a történeti autenticitást és a patak spirituális hitelességét ${ }^{6}$, illetve a város szerves fejlődését állítjuk középpontba, akkor Cshonggjecshon revitalizációjának sikere kétséges. A Cshonggjecshon patak történetéhez és az eredményképp létrejött, sajátosan ellentmondásos helyzethez hasonlót másutt is láthattunk már, ilyen volt a bostoni Central Artery sorsa, de számos hasonló projekt zajlik Szöulban is, melyekre példa lehet a Kjongi Vonal Park és Skygarden (Koudela 2020).

Szöul egyes területeinek ökológiai rendszerét egyértelműen javítani szándékoznak a fenti fejlesztések, ám a város egész területére a legnagyobb hatással az azt körülölelő zöldöv van. Az 50-es és 60-as évek gyors népességnövekedése, a város egyre nagyobb országon belüli gazdasági szerepe egységes stratégiát kívánt, melyre a választ - legalábbis ökológiai értelemben - az 1971 és 1976 között létrehozott zöldöv adta meg. A terület mára 1566,8 négyzetkilométeres kiterjedésű, ami a teljes fővárosi térség (Szöul, Incshon és Jongin) 13,3 százalékát teszi ki, s amivel, közvetlenül Ontario után, a világ második legnagyobb zöldövének címét is kiérdemelte (Han et. al. 2017). Eközben népessége a térség alig több mint másfél százaléka. Céljainak megfelelően a zöldövben nem lehet fejleszteni, s kialakításakor a tulajdonosok kárpótlást sem kaptak, amennyiben nem történt kisajátítás, $\mathrm{s}$ a földtulajdon 80 százaléka máig magántulajdonban maradt. Külön érdekesség, hogy a várost körülölelő hegyes erdős területet már a Csoszon dinasztia kezdetén, a 14-15. század fordulóján tilalom védte, semmilyen fejlesztést vagy a föld bárminemü hasznosítását lehetetlenné téve. Az erre vonatkozó királyi rendelet kelte 1397 volt (Bengston és Youn 2005).

A zöldöv kialakítását Szöul esetében számtalan ok vezérelte, ám más nagyvárosokkal ellentétben a legfontosabb a nemzetbiztonsági szempont volt. A zöldöv kialakításának azonban számtalan egyéb célja is akadt, mint a Szöul körüli illegális nyomornegyedek felszámolása vagy a város területnövekedésének meggátolása. A hatvanas években a városvezetés törekvése ugyanis, hogy ez utóbbit, tehát a lakott területk növekedését, megakadályozza, sikertelen maradt. További szempont volt még az ipari koncentráció mérséklése. Emellett a kormány a zöldövet lehetőségnek tekintette, hogy megakadályozza a telekspekulációkat a fővárosi térségben. A mezőgazdasági művelésre kialakított területek ugyanakkor a főváros élelmiszerbiztonságát is hivatottak biztosítani, s természetesen a környezeti és erőforrások védelme ugyancsak szerepet ját-

\footnotetext{
${ }^{6}$ A tárgyak, így természeti képződmények animista felfogása és spirituális jelentősége Kelet-Ázsiában, azon belül Dél-Koreában is nagyobb, mint nyugaton.
} 
szott a fejlesztésben, különösen, mivel a háború és a gyors iparosodás jelentős erdőkivágással és talajerózióval járt (Bae 1998). Habár a katonai kockázatok lényegében nem változtak, azok jellege átalakult. Ugyanakkor a környezetvédelmi szempont a város és gazdasága növekedésével egyre nagyobb hangsúlyt kapott - ma Szöul légszennyezettsége a szálló por tekintetében két és félszerese az elfogadható értéknek (Park et. al. 2015). Mindez egyszerre szolgálja a környezet fenntarthatóságát és a rekreációt: szűri a Kína felől szálló port, és parkjaival, hegyeivel teret biztosít a város lakónak egészségük megőrzésére (Bae és Jun 2003; Lee 2004; South Korea. Environmental Policies).

\section{Új fejlesztő eszközök sajátos jelentéssel}

A továbbiakban az utóbbi években egyre fontosabb szerepet játszó IT-eszközökkel foglalkozunk, melyek között kiemelendő az Eco Mileage rendszer és kártya bevezetése. Emellett a köz- és otthoni világítás fejlesztése és LED-lámpákra cserélése, valamint az épületek utólagos felszerelése és a megújuló energiaforrások (napelem) támogatása mind részét képezi a fenntartható város kialakításának Szöulban. A károsanyag-kibocsátás mérséklését célozta az atomenergiába történő jelentős beruházás is, ami paradox módon további gondokat szült, s az abból származó hulladék elhelyezésének problémáját váltotta ki. Erre eleinte átmeneti megoldásokat hoztak létre, 2005-ben azonban megszületett Szöul és Nagyvárosi Térsége Első Mesterterve a Levegőminőség Javítására (2005-2014), majd 2013-ban a második terv a 2015-2024-es tervezési időszakra. A tervek elsődleges célja a szállópor és a nitrogéndioxid csökkentése. A cél elérésére szolgáló intézkedések részben a gépjármű-gazdálkodásból áll, beleértve a működő járművek kipufogógáz-kibocsátásának csökkentésére irányuló projektet, részben a kibocsátási létesítmények irányítását foglalja magába, ide sorolva a nagy létesítmények teljes terhelésirányítási rendszerét, valamint a környezetbarát energia és a városok irányítását is (ECOREA 2015). A 2010-es évek végén nagyszabású kampány igyekezett meggyőzni a közvéleményt a tartósabb megoldások szükségességéről, melyek azonban legfőképp további lerakók létesítését jelentenék.

2010-ben Szöulban egy 8,2 milliárd dolláros szélerőmű létesítésébe kezdtek, a rákövetkező évben a kormány másfélmillió, a megújuló energiatermelés területén létrehozandó munkahely támogatását kezdeményezte, és 2030-ra teljes energiatermelésének 20\%-át célozza ily módon előállítani (Chung 2017). 2019-ben Korea és Kína megállapodott abban, hogy mesterséges esőket hoznak létre felhővetéssel ${ }^{7}$, így csökkentve Szöul és Sanghaj levegőszennyezettsé-

\footnotetext{
${ }^{7}$ Az úgynevezett felhővetés során - repülőről vagy a talajról - olyan vegyi anyagokat - például nátrum- vagy kálium-klorid - juttatnak a légkörbe, a vízfelhőkbe, amelyek esőcseppek kialakulását generálják, emellett a jégeső és a köd terjedését gátolják.
} 
gét, a várt eredmény, vagyis a nagyobb csapadékmennyiség azonban elmaradt (South Korea plans).

A városiasodás és a tékozló fogyasztói szokások általánossá válása rengeteg környezeti problémát hívott életre. A levegőszennyezés, különösen a CO2-kibocsátás Szöul túlnépesedésének köszönhetően folyamatosan nőtt a 60-as éveket követő évtizedekben. Ide sorolhatók a környezeti kihívással kapcsolatos várostervezési megoldások, különösen a zöldöv összetett szabályozó szerepe és a felszíni vizeket érintő problémák és megoldásuk, valamint ezek társadalmi vonatkozása. A fogyasztási szokások átalakulása környezeti problémákat von magával, amit a gazdaság növekedése és a részben ebből, részben társadalompolitikai erőfeszítésekből következő társadalmi különbségek kiegyenlítődése is fokoz. Ha ugyanis mindenki többet és erőfeszítés nélkül fogyaszt, az nagyobb környezeti terhelést eredményez. A gazdasági teljesítmény csökkenése azonban nem fordítja vissza ezt a folyamatot, hiszen az a szokásokon alig és csak lassan tud változtatni, csupán az okozott problémák kezelésére szánható forrásokat csökkenti.

A városi infrastruktúra fejlesztése azonban nem szükségszerüen ront a helyzeten. A modern várostervezés és technológia korában az úthálózat kibővítése egyet jelentett a városi szétterüléssel, a növekvő személyautó-használattal és az abból fakadó károsanyag-kibocsátással. A csatornahálózat felszámolta ugyan a fertőző betegségek jelentős részét, ám a felszíni és talajvizek hagyományos egyensúlyának felborításával azok élővilágát is súlyosan károsította. Ezzel ellentétben, a posztmodern városok problémái már egy lépéssel előbbre tartanak. Szöulban máris az agglomeráció népessége és ipara növekszik a leggyorsabban, tehát a környezeti problémák is itt a legakutabbak (Kim és Pauleit 2007).

\section{A zöldtető}

A fenntartható város koncepció egyik gyakori eleme és megvalósításának eszköze a zöldtető. Állítólag ilyeneket már a 20. század elején installáltak Németországban, ahol a vegetációt azért telepítették a tetőkre, hogy enyhítsék a napsugárzás tetőszerkezetre gyakorolt káros fizikai hatásait, a korai zöldtetőket egyúttal tűzálló szerkezetekként is alkalmazták (Köhler 2003). Koreában először a 70-es években, szállodákon és áruházakon jelent meg, az elmúlt negyven évben mindenesetre általánosan elfogadott eszközzé vált a városi környezeti problémák kezelésében. 2009-ben Toronto volt az első város, ami jogszabályban kötelezte az új intézményeket, kereskedelmi és lakóépületeket, melyek hat emeletnél magasabbak és 2,000 m2-nél nagyobb tetőfelülettel épülnek, hogy tetőszerkezetüket legalább 50\%-ban zöldtetővel fedjék-20-60\%-ban - a már meglévő épületek pedig pénzbeli támogatást kapnak erre a célra.

A zöldtető számos előnyét szokták kiemelni: csökkenti a meleget (visszaveri a napfényt, megelőzi a hőszigetek kialakulását), felfogja, lassítja a nagy eső- 
ket, növeli a biodiverzitást, javítja az energiahatékonyságot, tisztítja a levegőt, csökkenti a zajszennyezést, növeli a zöldfelületet, szenet köt meg, esztétikus, sőt oktatási eszközként, helyszínként is használható (Wescott és Sundell 2016). Mindemellett, habár előállítási költsége magasabb a hagyományos tetőknél, a tető élettartamának növekedése, az ingatlan árának emelkedése és az energiamegtakarítás együttesen költséghatékonyabb megoldássá teszi (Bianchini és Hewage 2012; Carter és Keeler 2008).

Mások a hátrányait emelik ki: a zöldtető csak a tetőn csökkenti a hőt, mert a szél elfújja a hủvösebb levegőt, mielőtt az az utcaszinten is hatna, éjszaka nem hatékony, mert nincs párolgás és a növények is hőt adnak le. Nemcsak a kiépítése drága, hanem a fenntartása is, jobb (és drágább) szigetelést igényel, nemcsak a víz, hanem a kártevő rovarok ellen is; nehéz, így a már meglévő épületeknél statikai problémákat jelent, az újaknál további költséget. A zöld és hideg tető lassítja a tenger felől fújó szeleket, ezzel rontja a levegőminőséget, miközben melegíti a szélirányos területeket, a felszálló párák csökkenésével pedig csökkenti a csapadékot (Currie és Bass 2008; Getter és Rowe 2006).

A zöldtető azonban nem csak közvetlen ökológiai előnyökkel jár(hat). Az olyan városi környezetben élő társadalom számára, mint Szöul, az elérhető, közeli zöldterület „megfizethetetlen” előnyöket jelent: pihenést, kikapcsolódást és rekreációt - összességében akár egy egészen új életstílus és szemlélet kialakulását is elősegítheti. Szöul területének több mint 50\%-a vízhatlan felület, ezt alig haladja meg a beépített terület aránya. A fennmaradó terület az erdők, folyók és parkok együttese (Kim, H. et al. 2016). Szöulban az egy főre eső városi zöldterület ${ }^{8}$ a legkisebb Korea városai közt, és a világ nagyvárosainak összehasonlításában is igen alacsony: 4,38 $\mathrm{m}^{2}$ volt 2019-ban. Összehasonlításképpen ez a szám Párizsban $13 \mathrm{~m} 2$, New Yorkban $23 \mathrm{~m}^{2}$ és Londonban $27 \mathrm{~m}^{2}$ (Jang 2019). A teljes, egy főre eső zöldterület az ENSZ Humanitárius Ügyek Koordinációs Hivatala (OCHA 2018) OECD-adatokon alapuló kimutatása szerint Szöulban $133 \mathrm{~m}^{2}$, míg Párizsban $1070 \mathrm{~m}^{2}$, New Yorkban $658 \mathrm{~m}^{2}$, Londonban pedig $436 \mathrm{~m}^{2}$ volt 2014-ben. Ebben az adatbázisban szerepel Budapest is, ahol az egy főre eső zöldterület $1187 \mathrm{~m}^{2}$ volt 2014-ben. ${ }^{9}$ A Szöul 2030 tervben (Kim, I-h 2015) a zöldtetők hálózatának kiépítése egyszerre célozza a város energiafogyasztásának, a csatornahálózat túlterhelésének és az áradások kockázatának csökkentését, egyúttal a város esztétikai értékének növelését. A zöldtetők

\footnotetext{
${ }^{8}$ A városi zöldterület a városok növényzettel vagy erdővel borított területeire vonatkozik, amelyekből kizárják a természetes erdőket vagy parkokat. Valahogyan elterjedt az a mém, hogy a WHO (2010) ajánlása minimum 9 m2/fö, amit az idézett dokumentum egyáltalán nem tartalmaz.

9 Ezek a számítások önmagukban semmitmondók, hiszen csupán az adott közigazgatási területen élők és az ott fellelhető zöldterületek arányát mutatják, sem a hozzáférést, sem a környezeti szerepükről nem szólnak. A legalacsonyabb értéket így Bari képviseli Olaszországban 0,43-os értékkel, vele szemben Torontóban 9016 m2 zöldterület jut egy főre. Különösebb helyismeret nélkül is egyértelmű a szélsőséges értékek tartalmi torzítása: nem élnek huzsonegyezerszer jobb, természethez közelibb környezetben a torontóiak, mint, aki Bariban él.
} 
elterjedésének támogatása egyszerre jelent meg a zöldutak tervével, melynek lényege, hogy a zöldterületek méretének növelése mellett az elszigetelt zöldterületeket is összekösse. Ennek érdekében számos helyen zajlott sávszükítés és a járdák és folyók felújítása. Ugyancsak a terv része volt, hogy Szöul minden iskolájában parkot alakítsanak ki.

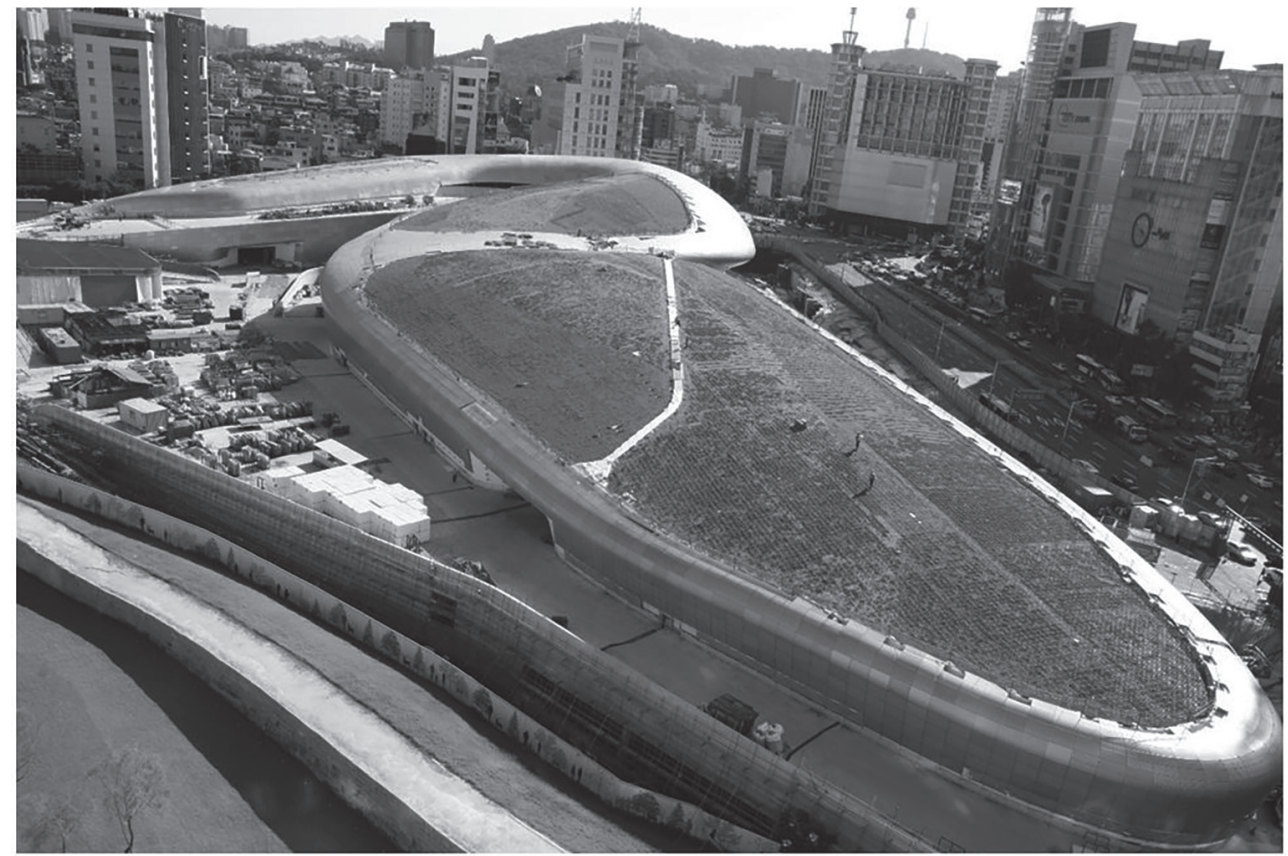

1. kép: Szöul Dongdaemun Design Plaza, a teljes tető, $20000 \mathrm{~m} 2$ zöld felületet kapott (BRM, Building \& Roof Management, Firestone UltraPly TPO)

Egy beható vizsgálat nyomán bebizonyosodott, hogy Kjonggi tartományban a potenciális zöldtetőnek beépíthető háztetők nagyobb felületet jelentenek, mint az összes meglévő zöldfelület együttvéve (Son 2018). A fenti előnyök hálózata továbbszőhető, ha az esztétikai élményhez hozzátesszük a kilátást, amit a tető nyújt egy földszinti parkhoz képest, ha az oktatás mellé általánosabb turisztikai funkciókat társítunk, és ha mindezt kiegészítjük a mezőgazdasági felhasználás lehetőségével. Bármekkora is a hátrányok okozta többletkiadás, az előnyök kvalitatív természetük miatt igen nehezen mérhetők. A változatosság, a környezet élhetőbbé tétele olyan sokrétű kölcsönhatásokat hív életre, melyek megítélésünk szerint a városi társadalom egészére, és különösen az érintett környék lakosságára, közösségeire mindenképpen pozitívan hatnak. Különösen így van ez a zöldterületekben szükölködő Szöulban.

A tetőtéri kertek egyúttal kulturális értéket is képviselnek, ami számos felhasználási területekre kiterjed. A tetőtéri kert alkalmas a természettel való kapcsolatteremtéshez és személyes kapcsolatokra egyaránt, különösen Szöulban, ahol mindehhez nincs, vagy csak nagyon kevés a megfelelő zöldterület. Ezeket a tevékenységeket pedig a városi élet számára kiemelet értékekké 
alakíthatják mindezen mesterséges zöldterületek. A zöldtető tehát közvetett hatást gyakorolhat a város ökológiai rendszerére, amennyiben környezettudatosabb szemlélet kialakítását segíti elő már a fiatal kortól kezdődően - ebben az értelemben nem maga a közvetlen környezeti hatás, hanem az információs értéke a legfontosabb tényező -, egyúttal közösségfejlesztő szerepe van.

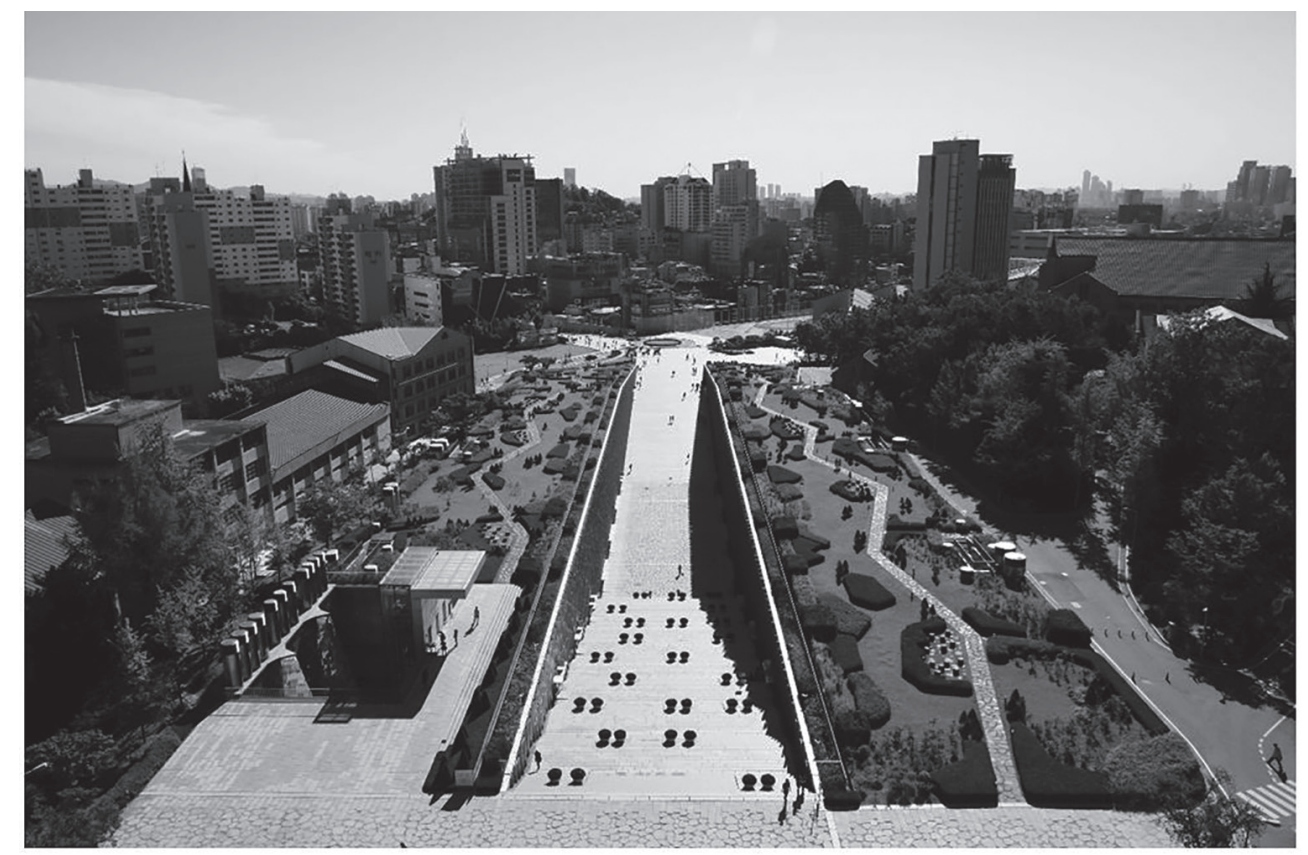

2. kép: EWHA Womans University, Szöul (ISEP, International Student Exchange Programs)

\section{Mesterséges hegyek}

A természet iránti vágy egyre sajátosabb formákban mutatkozik meg Szöulban - talán legérdekesebb mind közül a viszonylag új divat, hogy mesterséges hegyeket építsenek a lakótelepek közepére. A Koreai-félszigetet 70\%-ban hegyek borítják, nem csoda, ha az évszázadok alatt mitikus vonzalom alakult ki az emberekben, s a sámánizmus hiedelemvilágában túlvilági erőt tulajdonítanak a hegyeknek. Az ezredfordulót követően egyes új lakóépületek tervezésekor már mesterséges hegyeket is hozzáadtak az építmények sorához - némelyik eléri a húsz métert, és akár 2 millió dollárba kerülhet. Ebből is látszik, hogy ez elsősorban a tehetősebbek számára kínál természeti élményt a városi dzsungelben -, az építéshez ráadásul igyekeznek különleges köveket és bonszaiokat kiválogatni, és az ország híres hegyeit utánozni (Ko 2019). A mesterséges hegyek építése lassan önálló művészeti ággá válik.

A műhegyek spirituális energiát árasztanak, szerencsét és egészséget hoznak, építésük a fengsuj hagyományát követi, a hagyományos esztétikai kate- 
gória koreai neve csinkjong szanszu, vagyis valódi, valóban látható tájkép, jelentése pedig a természet folyamatos megfigyelése és a természettel való harmónia. A szent hegyek másolatai tehát nem csupán az ingatlanok esztétikai és eladási értékét növeli, hanem lelki megnyugvást is nyújt a lakók számára. Kim Szungku személyében már fotóművész is van, aki az ilyen hegyek specialistája, tekintve, hogy húszas éveit maga is építkezéseken dolgozta végig, pontosan ismeri az építmények szerkezetét is. Nem szabad alulértékelnünk a város átalakulásának az ilyen elszigetelt és apró morzsáit. A nyugati szemlélő számára talán hókuszpókusznak tűnő mentális tartalmak mélyebben gyökereznek a koreai gondolkodásmódban, mint hinnénk, s jelen kontextusban a meglévő erőforrások megfelelő felhasználása a cél, nem azok megváltoztatása. Ha a károsanyag-kibocsátás csökkentéséhez (legalábbis részben) a környezettudatos magatartáson keresztül vezet az út, és azt zöldtetők és műhegyek segítségével lehet megerősíteni, akkor nem érdemes figyelmen kívül hagyni azokat.

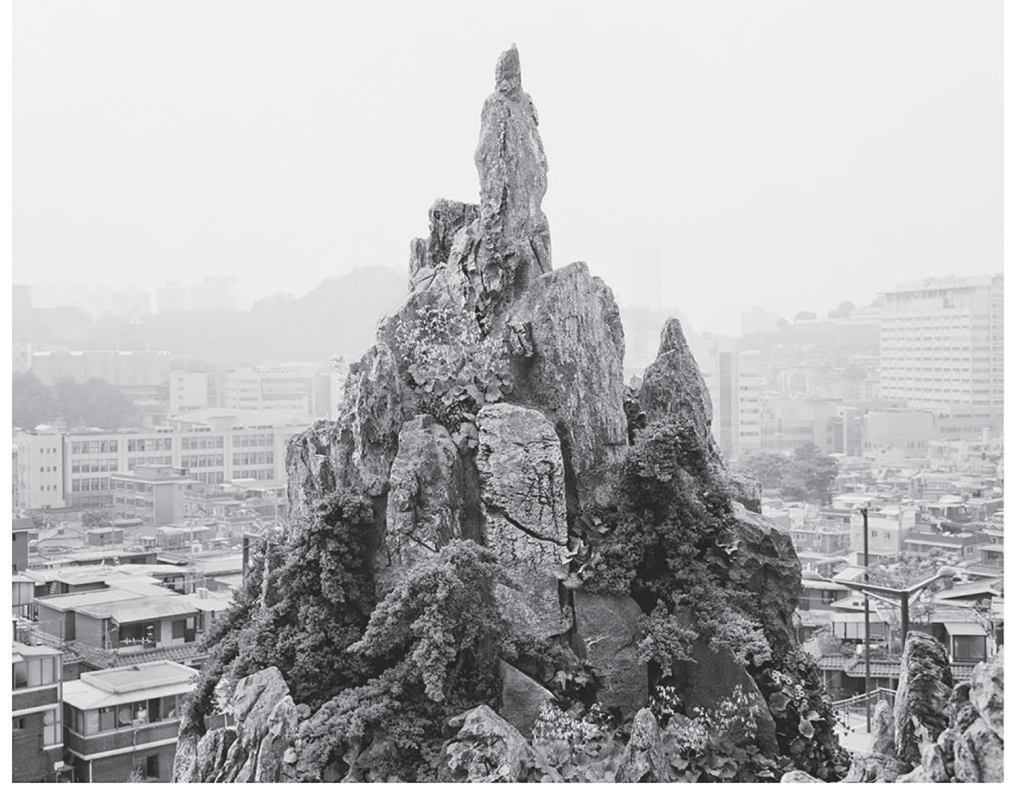

3. kép: Kim Szungku „A tojáson ülő páva energiája” - a Szodalszan hegy (a Szöuli Nemzeti Temetőnél) mesterséges mása Szöulban, 2014. (Ko 2019)

\section{Információs technológiai eszközök a környezettudatosság érdekében}

Szöul élhetőbbé tételének egyik sarokköve a fenntarthatóság kialakítása és a természeti környezet védelme. A nem is olyan régi tapasztalatok nyomán mára meghatározó program az atomenergia helyettesítése más megújuló energiaforrásokkal és az energiafogyasztás csökkentésével. Mindez természetesen a progresszív városvezetési szemléletben, a lakók bevonásával történik. Ahogyan a kulturális örökségvédelem a lakókat kérdezte meg, vajon mely városi tereket 
tekintenek a jövő örökségének, úgy vonja be az Eco-Mileage System, Szöul energiatakarékossági programja, a polgárokat a város fenntarthatóságába. Teszi ezt úgy, hogy ösztönzőket nyújt a tagháztartásoknak és szervezeteknek, azért, hogy legalább 10\%-kal csökkentsék a havi átlaghoz képest a villamosenergia-, a víz, gáz- és a fütésfelhasználásukat, ehhez az előző két év értékeit viszonyításai alapként véve. A program neve az ecofriendly (környezetbarát) és a mileage (távolság) szavakból származik, ami arra utal, hogy a program célja egy futásteljesítmény-felhalmozási rendszer létrehozása. Az ösztönzők közé tartoznak a környezetbarát háztartási termékek, az utazási kártya feltöltés, hagyományos piacokon beváltható ajándékutalványok és hitelkártyapontok.

2014-et követően 1,42 millió polgár vett részt az eco-mileage projektben. A projektben részt vevő polgárok 300 tonnával csökkentették az üvegházhatású gázokat, és 151168 TOE (tonne of oil equivalent - olajegyenérték) energiát takarítottak meg. Ez nagyjából egyenértékủ egy akkora erdő által megtakarított gázmennyiséggel, ami 93-szor nagyobb, mint a szöuli Joi-sziget, vagy 190 autó éves üzemeltetéséhez felhasznált energiamennyiséggel (Eco-Mileage System). Ahogy egy interjúban az önkormányzat egy hivatalnoka megjegyzi: „Az energiacsökkentés mértéke megegyezik azzal, amit egy Joi-szigetnél ${ }^{10} 542$-szer nagyobb erdő létrehozásával vagy 256 millió 30 éves fenyőfa elültetésével érhettünk volna el” (Kang 2018).

Szöulban az energiafogyasztás számítási módszerét a korábbi, egy adott időpontban mért mennyiség helyett hat hónap alatt felhasznált átlagos menynyiségre váltották át, ezzel is ösztönözve a folyamatos energiamegtakarítást. Jelenleg a város monitorozza a háztartások energiafogyasztását, és minden mért hat hónapos periódusból kiválasztja azokat a háztartásokat, amelyek havi 10\%-ot megtakarítottak az előző két év havi átlagához képest. Azok az apartmankomplexumok vagy kereskedelmi épületek, amelyek kiemelkedő eredményeket mutatnak az üvegházhatású gázok kibocsátásának csökkentésében, az önkormányzat 5-10 millió KRW összegű támogatást nyújt, amit nagyobb hatékonyságú eszközökre való áttéréshez lehet felhasználni.

A program bővülése és a tagság növekedése nyomán bevezették az Eco-Mileage Kártya rendszert, hogy ezzel csökkentésék a program költségvetési terheit. 2018-ig 793679 kártyát bocsátottak ki. Szöul egyúttal más városok számára is népszerűsíteni kezdte a kártyát, ennek eredményeként országosan 3249252 kártyát adtak ki. A rendszer nemcsak közvetlen előnyöket nyújt a polgárok számára, egyúttal megerősíti a környezetvédelem iránti elkötelezettségüket is; mindez a városi közigazgatás, a hitelkártya-társaság, a pénzügyi intézmények, a gyártók és a kiskereskedők együttműködésének eredménye. A rendszer nagyon kevés költséggel jár a városvezetés számára, miközben jelentős változásokhoz vezet.

\footnotetext{
${ }^{10}$ Sziget a Han folyóban, Szöulban. A kétféle érték ellentmondása a kétféle számításból ered, a valóságban mindkettő csupán a nagyságrend érzékeltetésére szolgálhat.
} 
A fenti ösztönzők mellett a program elősegíti a polgárokkal folytatott kétirányú kommunikációt: az Eco-Mileage weboldal közzéteszi a polgárok energiatakarékossági tanácsait, tájékoztatja a polgárokat az új városi programokról, például az Energiaklinikáról, amely ingyenes kiszállást és energiadiagnosztikai szolgáltatás nyújt a részt vevő épületek és háztartások számára. Azok számára (például egyedülálló idősek), akik otthon nem rendelkeznek számítógéppel, vagy nem tudják használni azokat, létrehoztak egy belvárosi központot is; a felelős tisztviselők mellett az egyes központokban ideiglenes diákmunkatársak segítenek nekik az online jelentkezésben (Eco-Mileage System).

Találunk azonban más eszközöket is a városvezetés kezében. Ilyen a U-City ${ }^{11}$, melynek célja olyan épített környezet megteremtése, amelyben bármely polgár bármilyen szolgáltatást bárhol és bármikor igénybe vehet bármilyen IKT-eszközön (információs és kommunikációs technológia) keresztül (Lee et al. 2008). A digitális kapcsolatok összetett hálózatba szervezése egyszerủ és gyors hozzáférést biztosít az intelligens szolgáltatásokhoz és információkhoz a város bármely részén. A városi infrastruktúra technikai fejlesztése tehát ismét alakíthatja a városi lakosok életmódját, és ezáltal elősegítheti a városi lakosok környezetbarát és környezettudatos gondolkodását. A U-City lehetséges pozitív környezeti hatásának ábrázolása előtt azonban fontos bemutatni az alapvető technológiát. A mindenütt jelen lévő számítástechnika középpontjában az épületek és lakók közötti, a várost átszövő nagysebességű vezeték nélküli internetszolgáltatás áll. Ez egy hatalmas virtuális hálózatot hoz létre, amelyben az információk szabadon hozzáférhetők, amit vezeték nélküli eszközök, például okostelefonok és laptopok számára nyújtanak.

E technológiák közül a legelterjedtebb a szélessávú konvergenciahálózat, amely a mindenütt jelen levő számítástechnikai szolgáltatás gerince $50 \mathrm{Mb}$ ps-tól 100 Mbps-ig terjedő sebességgel. A további technológiák, mint például a mindenütt jelenlévő szenzorhálózat és a helyalapú szolgáltatások, mind erre a kiterjedt nagysebességű internetes hálózatra építkeznek. Az előbbi bármilyen vezetékes vagy vezeték nélküli eszköz számára lehetővé teszi a más eszközökből vagy a környezetbe beágyazott számítástechnikai eszközökből származó információkhoz való hozzáférést. A Connected Urban Development (Összekapcsolt városfejlesztés) a Cisco beruházása volt egy 2006-ot követő ötéves fejlesztési terv keretében San Franciscóban, Amszterdamban és Szöulban, majd további városok is csatlakoztak hozzá. Legfőbb célja a CO2-kibocsátás csökkentése volt, de egyúttal a város gazdasági növekedését is támogatta azzal, hogy egyben a természeti erőforrások teljesen újszerű felhasználását vezette be (Villa 2010: 108).

Szöul rendkívül gyors internetfejlesztési ütemét használja ki a Personal Travel Assistant (Személyes utazási asszisztens) rendszer (Cisco). A PTA-szol-

\footnotetext{
${ }^{11}$ Sziget a Han folyóban, Szöulban. A kétféle érték ellentmondása a kétféle számításból ered, a valóságban mindkettő csupán a nagyságrend érzékeltetésére szolgálhat.
} 
gáltatás valós idejű információkat szolgáltat a tömegközlekedésről, például a legkevesebb szén-dioxid-kibocsátással járó útvonalakról, a zöld közlekedési eszközök érkezési idejéről és más környezetbarát lehetőségekről. Szöul már így is a legfejlettebb tömegközlekedéssel rendelkezik, a lakosság 80\%-a tíz percen belül lakik valamely buszmegállótól (OECD 2017b). A projekt további célja a városi torlódások csökkentése, amely az egyik legnagyobb probléma, amellyel Szöul lakói szembesülnek. A dugók oka, és egyes esetekben következménye más városi problémáknak is, így például a szmog, a kisgyermekek asztmája, a magas szén-dioxid-kibocsátási szint és az életminőség romlása, mind összefüggésbe hozható vele.

Számos egyéb, a fenntarthatóságot támogató szolgáltatás is található Szöulban, melyek ugyancsak a várost átszövő internetes architektúrára támaszkodnak, így a személyautók számára a legkedvezőbb költségű (beleértve az úthasználati díjakat is) útvonalat kiszámoló alkalmazást. Az IKT-rendszer részét képező kiterjedt PTA-szolgáltatás révén a városi lakosság viselkedése környezettudatossá válhat és a szén-dioxid-kibocsátással kapcsolatos nézeteik megváltozhatnak, így maga a környezeti probléma is enyhülhet. A PTA a fenntartható város közvetlen kezelési mechanizmusainak egyike, ám a toronyházak CO2-kibocsátásának csökkentése és a város hatékonyabb szervezése érdekében más technológiák is folyamatos fejlesztés alatt állnak. Ide tartozik a hulladékgazdálkodás is, Szöulban alapvető változások zajlottak ezen a téren is; nem célunk minden környezetgazdálkodási fejlesztést felsorolni, csupán megemlítjük a hulladékalapú energiaelőállítást, ami számunkra igazán fontos tényező, az a társadalmi célú gondolkodás megjelenése és hatása a városfejlesztésben és -gazdálkodásban. Hiábavaló ugyanis minden fejlesztés, ha nem áll összhangban a lakosság gondolkodásával és szokásaival, azok megváltoztatása teszi igazán hatékonnyá a környezet hosszú távú átalakítását.

\section{Összegzés}

A természeti környezet átalakítása nem szükségképpen jelenti azt, hogy az ember és a természet „eredeti harmonikus viszonya” elvész vagy megromlik. A város persze mesterséges környezet, annak emberközpontú fejlesztése csakis sajátos eszközeivel és sajátos környezeti elemeinek, és természetesen magának az individuum fontosságának a figyelembevételével lehetséges. Mindezekhez sajátos körülményeket kell figyelembe venni Kelet-Ázsiában, azon belül Szöulban. A fenntarthatóság növeléséhez nem a város felülről irányított, mestertervvel megalkotott jellegének az erősítése az egyedül megfelelő út, hanem olyan rendszer létrehozása, amiben az egyes szereplők, vagyis a városlakók válnak érdekelt szereplővé. Ez több mint egyszerű motiválás, hiszen a közvetlen érdekeltté tételen túl a környezettudatosságot is fejleszti, vagyis önműködővé teszi a rendszert. Az Eco Mileage System azontúl, hogy rövid távon mérsékli a károsanyag-kibocsátást, a városi életről alkotott elkép- 
zeléseket is formálja, aktív részvételre serkent. A zöldtető olyan tereket hoz létre, melyek közvetlen ökológiai funkciója vitatható, ám az egyén környezethez való viszonyulását mindenképpen egy fenntartható rendszer igényének irányába tereli. A mesterséges hegyek talán elsőre gazdagok hóbortjának tűnnek, ám azt a képet erősítik, mely a meglévő rossz környezet nem végleges jellegét, átalakíthatóságát hirdeti. Azt sugallják, hogy lehetőség van a legsűrübb betondzsungelben is arra, hogy egy aprócska természetet hozzunk a mindennapokba, nem utolsó sorban pedig közösségi tereket alakítsunk ki, melyek fizikai jellegükkel eleve magukban hordozzák azt a pozitív értékszemléletet, ami a fenntartható városok hosszútávú működéséhez elengedhetetlen, mindezt az ember és természet hagyományos spirituális viszonyrendszerébe ágyazva történelmi és kulturális kontextust teremtenek.

Mindezek értékelésekor legalább kétféle szempontból érdemes figyelembe venni a sajátos kelet-ázsiai környezetet. Egyfelől a gazdaságpolitika és a társadalom irányításának eszközei számára általában is mást jelent a felülről irányítás, mint a nyugati társadalmakban. Ennek részletes magyarázatára ezúttal nincs lehetőségünk kitérni, de elégséges, ha a fejlesztő állam (Johnson 1982) modelljét és gyakorlati alkalmazását integráljuk a gondolatmenetünkbe, hogy máris érthetővé váljon: a társadalom alulról szerveződő intézményeit és folyamatait miért lehet mégis egy mesterterv segítségével jól menedzselni, felülről elősegíteni. A másik sajátos környezeti feltétel a természethez és spiritualitáshoz való viszony történeti-mentális gyökereit jelenti, azt a sajátos gondolkodást, amit számos területen tapasztalhatunk a tágabb régióban (Koudela 2018). Mindezek figyelembevételével a fenntartható város létrehozásának, $s$ az infokommunikációs eszközök szerepének helyét sajátos megközelítésben tárhattuk fel Szöulban.

\section{Irodalom}

Ahn, Kwang-Soon (안광순) „대도시 개발사업의 주류, 도시정비사업” (Mainstream of Metropolitan Development, Urban Rearrangement Project), Ilkam Real Estate Law Review, (2015), Vol. 10. pp. 29-60.

Baker, Don Korean Spirituality, Univesity of Hawai’i Press, Honolulu, 2008.

Bae, Chang-Hee Christine - Myung-Jin Jun „Counterfactual planning: What if there had been no greenbelt in Seoul?”, Journal of Planning Education and Research. (2003) Vol. 22. No. 4. pp. 374-383.

Bae, Chang-Hee Christine „Korea’s greenbelts: impacts and options for change”, Pacific Rim Law \& Policy Journal, (1998) Vo. 7. No. 3. pp. 479-502. 
Bengston, David N. - Youn Yeo-Chang „Seoul's greenbelt: an experiment in urban containment”, in Bengston, David N. (ed.) Policies for managing urban growth and landscape change: a key to conservation in the 21st century. Gen. Tech. Rep. NC-265. 2005, U.S. Department of Agriculture, Forest Service, North Central Research Station, St. Paul. pp. 27-34.

Bianchini, Fabricio and Kasun Hewage „Probabilistic social cost-benefit analysis for green roofs: A lifecycle approach”, Building and Environment. Vol. 58. (2012) No. 12. pp. 152-162. https://doi.org/10.1016/j.buildenv.2012.07.005

„BRM, Building and Roof Management, Firestone UltraPly TPO”, https://hu.pinterest.com/ BRMroofing/

Carter, Timothy and Andrew Keeler „Life-cycle cost-benefit analysis of extensive vegetated roof systems”, Journal of Environmental Management, Vol. 87. (2008) No. 3. pp. 350-363. doi:10.1016/j.jenvman.2007.01.024

Cho, Myung-Rae „The politics of urban nature restoration. The case of Cheonggyecheon restoration in Seoul, Korea”, International Development Planning Review, (2010) Vol. 32. No. 2. pp. 145-165. doi:10.3828/idpr.2010.05

Cho, Pil-Kyu (조필규) „도시정비사업 활성화 방안 연구 - 현행 도시정비사업 정책 평가를 통한 새 정부의 재개발 - 재건축사업 활성화 방안을 중심으로” (Research on Urban Improvement Promotion - By evaluating the current urban redevelopment projects, in promotion of redevelopment / reconstruction upon inauguration of the new president), (2013), Public Land Law Review, Vol. 61. pp. 83-105.

Choi, Ik-Chang, Hio-Jung Shin, Trung Thanh Nguyen and John Tenhunen „Water policy reforms in South Korea: A historical review and ongoing challenges for sustainable water governance and management”, Water, Vol. 9. (2017) No. 717. pp. 1-20. https://doi. org/10.3390/w9090717

Chung, Jane „South Korea finalizes energy plan to boost renewable power generation”, Reuters, December 29, 2017, https://www.reuters.com/article/us-southkorea-energy-policy/southkorea-finalizes-energy-plan-to-boost-renewable-power-generation-idUSKBN1EN0KT

„Cisco and the City of Seoul Launch Personal Travel Assistant Solution”, The Network, Cisco's Technology News Site, May 21, 2009, https://newsroom.cisco.com/press-release-content?ty pe=webcontentandarticleId $=4941556$

Csong Szung-Jöl (정승열) 도심속 낙원 서울숲 (Szöul erdő a város központjában), 금강일보, 2014.07.02

http://www.ggilbo.com/news/articleView.html?idxno=185212\#0BJz

Currie, Beth Anne and Brad Bass „Estimates of air pollution mitigation with green plants and green roofs using the UFORE model”, Urban Ecosystems, Vol. 11. (2008) No. 4. pp. 409-422. https://doi.org/10.1007/s11252-008-0054-y

„Eco-Mileage System. Seoul Solution”, Seoul, 2014-08-11, https://seoulsolution.kr/en/content/ eco-mileage-system-1

ECOREA „Urban Air Quality Management”, Environmental Review, Vol. 2. 2015, pp. 34-36. http://eng.me.go.kr/eng/file/readDownloadFile.do?fileId=121529\&fileSeq $=2$

„Environmental Performance Index”, (EPI 2016) Yale Center for Environmental Law and Policy - YCELP - Yale University, Yale Data-Driven Environmental Solutions Group Yale University, Center for International Earth Science Information Network - CIESIN Columbia University, and World Economic Forum - WEF. 2016. 
„Environmental Performance Index” (EPI 2020) Yale Center for Environmental Law \& Policy, 2020, https://epi.yale.edu/epi-results/2020/country/kor

„Environmental Performance Index” (EPI) Environmental Performance Index, 2016 Release (1950-2016). Palisades, NY: NASA Socioeconomic Data and Applications Center (SEDAC), https://doi.org/10.7927/H4FX77CS

Getter, Kristin L. and Bradley D. Rowe „The Role of Extensive Green Roofs in Sustainable Development”, HortScience, Vol. 41. (2006) No. 5. pp. 1276-1285. https://pdfs. semanticscholar.org/1d76/263bb51f60a1eaf6a4a02c128a3eba1c0a3b.pdf

Gross, Matthias „New Natures and Old Science: Hands-on Practice and Academic Research in Ecological Restoration”, Science Studies, (2002) Vol. 15 No. 2. pp. 17-35.

Gross, Matthias Inventing Nature: Ecological Restoration by Public Experiments. 2003, Lexington Books, Lanham.

Gross, Matthias „Ecological restoration as a real-world experiment: designing robust implementation strategies in an urban environment”, Public Understanding of Science, (2005) Vol. 14 No. 3. pp. 269-284.

Han, Haoying; Chen Huang; Kun-Hyuck Ahn; Xianfan Shu; Liyun Lin; Derong Qiu „The Effects of Greenbelt Policies on Land Development: Evidence from the Deregulation of the Greenbelt in the Seoul Metropolitan Area”, Sustainability, (2017) Vol. 9. No. 7. pp. 1259. doi:10.3390/su9071259

Hu,Elise „Armed With NASAData,South Korea ConfrontsIts Choking Smog”,NPR(NationalPublic Radio), October 10, 2017, https://www.npr.org/sections/parallels/2017/10/10/552264719/ armed-with-nasa-data-south-korea-confronts-its-choking-smog?t=1591349791364

„Ewha Womans University”, ISEP, International Student Exchange Programs, Seoul, 2020, https://search.isepstudyabroad.org/University/Detail/8a8401f2-3c50-4206-baf4-dd2fcac114d8

Jang, Lina „Seoul Has the Least Urban Green Space per Capita in the Country: Study”, Korea Bizwire, March 13, 2019, http://koreabizwire.com/seoul-has-the-least-urban-green-spaceper-capita-in-the-country-study/134044

Jeon Kyung-Sook (전경숙) "광주광역시의 도시 재생과 지속가능한 도시 성장 방안" (Urban regeneration and sustainable growth strategies in Gwangju metropolitan city) Journal of the Korean Urban Geographical Society, (2011) Vol. 14. No. 3. pp. 1-17. doi: 10.23841/ egsk.2011.14.1.1.

Kang, Seung-woo „Seung-wooSeoul's Eco-Mileage most efficient energy-saving program”, The Korea Times, Seung-wooSeoul's Eco-Mileage most efficient energy-saving program 201812-12, http://www.koreatimes.co.kr/www/nation/2020/01/281_260253.html

Kim, Hakkwan, Hanseok Jeong, Jihye Jeon and Seungjong Bae „The Impact of Impervious Surface on Water Quality and Its Threshold in Korea”, Water, Vol. 8. (2016) No. 4. pp. 111. https://doi.org/10.3390/w8040111

Kim, In-hee „2030 Seoul Plan”, Seoul Solution, Seoul, 2015-07-31, https://www.seoulsolution.kr/ en/content/2030-seoul-plan

Kim, Keun-Ho and Stephan Pauleit „Landscape character, biodiversity and land use planning: The case of Kwangju City Region, South Korea”, Land Use Policy, Vol. 24. (2007) No. 1. pp. 264-274. https://doi.org/10.1016/j.landusepol.2005.12.001

Ko, Stella „Photographer captures Seoul's artificial ,mountains”, CNN, 7th November 2019, https://edition.cnn.com/style/article/seoul-fake-mountain-photographer/index.html 
Koudela Pál „Észrevételek a kelet-ázsiai régió történeti-kulturális megközelítéséhez”, Orpheus Noster. Vol. 10. (2018) No. 3. pp. 37-56.

Koudela Pál „A városfejlesztés három útja Szöulban”, Tér Gazdaság Ember, (2020) Vol. 8. No. 3. pp. 81-108.

Koudela Pál és Yoo Jinil „Sesummu. Distinction, debate and features of hereditary mudang in contemporary South Korean society”, Acta Ethnographica Hungarica, (2014) Vol. 59. No. 2. pp. 429-440.

DOI: $\underline{\text { http://dx.doi.org/10.1556/AEthn.59.2014.2.12 }}$

Köhler, Manfred „Plant survival research and biodiversity: Lessons from Europe”, Paper presented at the First Annual Greening Rooftops for Sustainable Communities Conference, Awards and Trade Show, 20-30 May 2003, Chicago.

Kurniawan, Mukhamad „Dari Cheonggye ke Ciliwung”, Kompas.com, 04.10.2016, https:/l travel.kompas.com/read/2016/10/04/203200427/dari.cheonggye.ke.ciliwung?page=all

Lee, Shi Chul „Measuring Public Support for the Korean Green Belt Policy: A Multivariate Analysis”. Paper presented at the Association of Collegiate Schools of Planning 45th Annual Conference, Portland, 21- 4 October, 2004.

Lee, Sang-Heon, Tan Yigitcanlar, Jung-Hoon Han and Youn-Taik Lim „Ubiquitous urban infrastructure: Infrastructure planning and development in Korea”, Innovation: Management, Policy and Practice, Vol. 10. (2008) No. 2-3. pp. 282-292.

Moran, Daniel, Keiichiro Kanemoto, Magnus Jiborn, Richard Wood, Johannes Többen and Karen C. Seto „Carbon footprints of 13000 cities”, Environmental Research Letters, Vol. 13. (2018) No. 6. 064041.

Mullins, Paul D. „The Ubiquitous-Eco-City of Songdo: An Urban Systems Perspective on South Korea's Green City Approach”, Urban Planning, (2017) Vol. 2. No. 2. pp. 4-12. DOI: 10.17645/ up.v2i2.933

OCHA United Nations Office for the Coordination of Humanitarian Affairs, Green area per capita (square meters per capita). https://data.humdata.org/dataset/green-area-per-capitasquare-meters-per-capita

OECD Organisation for Economic Co-operation and Development, OECD Environmental Performance Reviews: Korea 2017. OECD Publishing, Paris, 2017a, https://doi. org/10.1787/9789264268265-en

OECD Organisation for Economic Co-operation and Development, Urban Transport Governance and Inclusive Development in Korea. OECD Publishing, Paris, 2017b, https://www.oecd.org/ korea/urban-transport-governance-and-inclusive-development-in-korea-9789264272637en.htm

OECD Organisation for Economic Co-operation and Development, Inclusive Growth in Seoul, Korea. OECD Publishing, Paris, 2018, https://www.oecd.org/governance/inclusive-growthin-seoul-korea-9789264290198-en.htm

Park, Jin-Ok; Sanghoo Yoon; Myung Hwan Na; Ho-Chun Song „The effects of air pollution on mortality in South Korea”, Procedia Environmental Sciences, (2015) Vol. 26. pp. 62-65.

Rees, William and Mathis Wackernagel „Urban ecological footprints. Why cities cannot be sustainable-And why they are a key to sustainability”, Environmental Impact Assessment Review, Vol. 16. (1996) No. 4-6. pp. 223-248.

https://doi.org/10.1016/S0195-9255(96)00022-4 
Rieh, Sun-Young - Ji-in Chang „Seoul, South Korea: Dismantling a highway - Cheonggyecheon Restoration Project”, in Sébastien Darchen, Glen Searle (eds.) Global Planning Innovations for Urban Sustainability. Routledge Abingdon. pp. 121-135.

Rugkhapan, Napong Tao - Martin J. Murray „Songdo IBD (International Business District): experimental prototype for the city of tomorrow?” International Planning Studies, (2019) Vol. 24. No. 3-4. pp. 272-292.

Shin, Pyeong-Woo (신평우) „A Study on the Improvement of Redevelopment. Reconstruction System on the Present Urban Regeneration Law” Public Land Law Review, Vol. 49, May, 2010 pp. 153-171.

South Korea. Environmental Policies. SGI Sustainable Governance Indicators, https://www.sginetwork.org/2018/South Korea/Environmental Policies

Son, Yong-hoon „Creation of Green Culture and Values in the Hanul Madang Rooftop Garden at Seoul National University”, in Shen, Zhenjiang, Ling Huang, KuangHui Peng and Jente Pai (eds.) Green City Planning and Practices in Asian Cities: Sustainable Development and Smart Growth in Urban Environments. Springer Cham, 2018, pp. 227-239

„South Korea plans artificial rain to reduce Seoul air pollution”, Aljazeera, 6 Mar 2019, https:/l www.aljazeera.com/news/2019/03/south-korea-plans-artificial-rain-reduce-seoul-airpollution-190306095309023.html

Townsend, Anthony M. Smart Cities: Big Data, Civic Hackers, and the Quest for a New Utopia. 2013, W.W. Norton \& Company, New York.

Villa, Nico „The Connected Urban Development Program”, in Wynants, Marleen (eds.) We Can Change the Weather: 100 Cases of Changeability. VUB Press, Brussels, 2010, pp. 108-109.

Wescott, Sarah and Valentia Sundell „Rooftop garden initiative”, Macalester College, 2016, https://www.macalester.edu/environmentalstudies/wp-content/uploads/sites/35/2016/06/ ENVI202-RooftopGarden2016.pdf

World Health Organization (WHO), Urban Planning, Environment and Health: From Evidence to Policy Action, Copenhagen, 2010, https://www.euro.who.int/ data/assets/pdf file/0004/114448/E93987.pdf 